PREACHING APOCRYPHA

IN ANGLO-SAXON ENGLAND 
This page intentionally left blank 


\section{Preaching Apocrypha in Anglo-Saxon England}

BRANDON W. HAWK 
(C) University of Toronto Press 2018

Toronto Buffalo London

utorontopress.com

Printed in the U.S.A.

ISBN 978-14875-0305-5

@ Printed on acid-free, $100 \%$ post-consumer recycled paper

with vegetable-based inks.

\section{Library and Archives Canada Cataloguing in Publication}

Hawk, Brandon W., author

Preaching apocrypha in Anglo-Saxon England / Brandon W. Hawk.

(Toronto Anglo-Saxon series ; 30)

Includes bibliographical references and index.

ISBN 978-1-4875-0305-5 (hardcover)

1. Apocryphal books - Criticism, interpretation, etc. - England - History -

To 1500. 2. Sermons, English (Old) - History and criticism. 3. England - Church history -449-1066. I. Title. II. Series: Toronto Anglo-Saxon series ; 30
BS1700.H39 2018
$229.00942^{\prime} 09021$
C2018-900766-4

This book was published with the generous assistance of a Book Subvention Award from the Medieval Academy of America.

University of Toronto Press acknowledges the financial assistance to its publishing program of the Canada Council for the Arts and the Ontario Arts Council, an agency of the Government of Ontario.

Canada Council for the Arts

Funded by the

Government of Canada

Financé par le gouvernement du Canada
Conseil des Arts du Canada

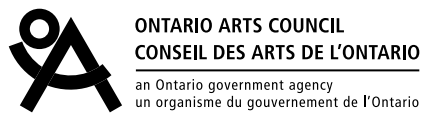


To my parents, Timothy and Susan Hawk 
This page intentionally left blank 